DOI: $10.5937 /$ hralsh2002078V

\title{
Mesenchymal stem cells and COVID-19
}

\author{
1,2Dragana Vujić, ${ }^{2}$ Marija Simić \\ ${ }^{1}$ University of Belgrade, Medical School \\ ${ }^{2}$ Mother and Child Health Care Institute of \\ Serbia "Dr Vukan Čupić" \\ Corresponding author: \\ Prof. Dragana Vujić, \\ University of Belgrade, Medical School, Mother \\ and Child Health Care Institute of Serbia \\ "Dr Vukan Čupić", Radoja Dakića 6-8, \\ 11070 Belgrade, Serbia \\ E-mail address: vujicdbg@gmail.com
}

Received 11 September 2020

Accepted 22 October 2020

\begin{abstract}
With the appearance of the first cases of COVID-19 infection, which had a severe clinical picture accompanied by respiratory insufficiency, as well as multiorgan dysfunction, mesenchymal stem cells became the subject of intensive research. The main cause of tissue and organ damage in patients with COVID-19 infection is thought to be a cytokine storm, which is the result of an imbalance in the regulation of the host immune system. Previous studies have shown that mesenchymal stem cells have an immunomodulatory effect and can prevent and reduce the cytokine storm triggered by the SARS-Cov-2 virus. Numerous clinical studies on the use of mesenchymal stem cells in patients with a severe clinical picture of COVID-19 are underway. Undoubtedly, cell therapy could be of great importance in the treatment of patients with a severe clinical picture of COVID-19, but it takes time to consider the efficacy and safety of such therapy, which is possible only through controlled multicenter clinical studies.
\end{abstract}

Key words: Mesenchymal stem cells; Therapy; COVID-19.

\section{INTRODUCTION}

In early December 2019, in the city of Wuhan, Hubei Province in China, a previously unknown viral infection was identified and spread rapidly beyond the borders of China. In the early phase, when the etiology of the disease was unknown, the first cases of pneumonia were described, which were accompanied by signs of acute respiratory distress syndrome, acute respiratory failure, and other complications that lead to death. China reported this phenomenon to the World Health Organization (WHO) on December 31st, 2019, and on January $7^{\text {th }}, 2020$. They identified the causative agent as a betacoronavirus, that uses the angiotensinconverting enzyme 2 (ACE2) receptor as the dominant mechanism for cell entry. Due to the rapid spread of the infection globally, WHO declared a pandemic on March 11th, 2020. The virus was designated as acute respiratory syndrome coronavirus 2 (SARS-CoV-2), and the disease as coronavirus disease 2019 (COVID-19) $[1,2]$.

In the first week of August 2020, it was confirmed that more than $18,000,000$ people became ill, and more than 700,000 died due to COVID-19 worldwide. It became apparent that developing safe and effective treatments for COVID-19 patients is of utmost urgency. Treatment of patients with COVID-19 depends on the severity of the clinical picture. In COVID-19 positive patients without symptoms, self-isolation is recommended, but in patients who have developed a picture of respiratory failure, it is necessary to apply mechanical ventilation, as well as antiviral therapy, antithrombotic therapy, vitamins, zinc supplementation, and immunotherapy [3-5].

Since the appearance of the first cases of patients with COVID-19, who had a severe clinical picture, mesenchymal stem cells (MSCs) were the focus of interest because of their ability to inhibit inflammation, cytokine storm, and secretory molecules that are antibacterial, antiviral, and analgesic. Since this is a non-standard therapy, it is recommended that MSCs be used exclusively in true clinical trials $[4,5]$.

\section{COVID-19 AND IMMUNE RESPONSES}

Studies to date have found that SARS-COV-2 interferes with the normal immune responses. The infection leads to the impaired immune system function and uncontrolled inflammatory response, especially in patients with severe clinical presentation. These patients may experience: lymphopenia, lymphocyte activation and dysfunction, granulocyte and monocyte abnormalities, an increase in immunoglobulin G (IgG) and total antibodies, and high cytokine levels [6]. 
One of the key findings, especially in patients with a severe clinical picture of COVID-19, is lymphopenia. It is a significant pathological finding and a good indicator of the clinical picture and treatment efficacy severity. The presence of lymphopenia at the onset of the disease may be an indication that the patient will develop a severe form of the disease. Previous studies have found that in addition to a significant reduction in the absolute number of lymphocytes, the number of cell subpopulations $\left(\mathrm{CD}^{+}{ }^{+} \mathrm{CD}^{+}{ }^{+}, \mathrm{NK}\right.$ cells, and $B$ cells) was significantly reduced in these patients. It was observed that in patients showing a severe clinical picture, lymphopenia is more pronounced, the absolute number of $\mathrm{CD}^{+} \mathrm{T}$ lymphocytes is significantly reduced, as well as the number of memory helper $\mathrm{T}$ lymphocytes. Examination of peripheral blood of patients with COVID-19 by flow cytometry showed that the percentage of $\mathrm{CD}^{+}$naïve $\mathrm{T}$ cells $\left(\mathrm{CD}^{+}, \mathrm{CD}^{+}\right.$, $\left.\mathrm{CD}^{2} 5 \mathrm{RA}^{+}\right)$increased, memory helper $\mathrm{T}$ cells $\left(\mathrm{CD}^{+}\right.$, $\mathrm{CD}^{+}, \mathrm{CD}^{2} 5 \mathrm{RO}^{+}$) decreased, and the percentage of $\mathrm{CD}^{+}, \mathrm{CD}^{+}{ }^{+}, \mathrm{CD}_{2} 8^{+}$cytotoxic T cells decreased. In $85 \%$ of patients with severe COVID-19, the mean absolute lymphocyte count was 800 , and their number was observed to decline with disease progression. The exact mechanisms of lymphopenia are still unclear. Also, in one of the conducted studies, it was noticed that the response of $\mathrm{CD}^{+} \mathrm{T}$ lymphocytes is faster than activated $\mathrm{CD}^{+}$response, and another study showed that activated $\mathrm{CD}^{+}$and $\mathrm{CD} 8^{+} \mathrm{T}$ lymphocytes appear in the blood before the first signs of the disease. Decreased lymphocyte counts may also be present in a small number of patients without a severe clinical picture and in pregnant women. During COVID-19 infection, changes in the number of granulocytes are registered, the ratio between granulocytes and lymphocytes changes, and the percentage of eosinophils, basophils, and monocytes decreases. In patients with a severe clinical picture, the number of neutrophils and the ratio between neutrophils and lymphocytes increases. This is a significant indicator of a severe clinical presentation and poor clinical outcome. However, in patients with a severe clinical presentation, a cytokine storm occurs. It is the result of the extreme production of inflammatory cytokines. The values for some interleukins, such as IL-1 $\beta$, IL-6, and IL-10, are exceptionally high in patients with a severe clinical presentation. Due to the activation of B and T lymphocytes, NK cells, neutrophils, monocytes, macrophages, dendritic cells, endothelial cells, and epithelial cells, proinflammatory cytokines are also produced in large quantities. Previous studies have indicated the existence of specific lgG and IgM class antibodies and that their titer correlated well with the severity of clinical presentation, i.e., that the increased number of B lymphocytes correlated with poorer survival [6-7].

\section{MESENCHYMAL STEM CELLS: CHARACTERISTICS AND FUNCTIONS}

Mesenchymal stem cells (MSCs) are adult multipotent stem cells that have the ability to self-renew and differentiate into various specialized cell types of mesodermal origin, such as adipocytes, osteocytes, and chondrocytes. Also, they are the focus of interest due to their immunomodulatory properties. All these features make them attractive for research and clinical application. They have been the subject of clinical trials for many years $[8,9]$.

A German pathologist, Cohnheim (1839-1884), hypothesized that there are cells in the bone marrow that have the ability to repair damaged tissue. Almost a century later, Friedenstein et al. confirmed his assumptions [10]. They were originally called "bone marrow fibroblasts" and then mesenchymal stromal cells. The Mesenchymal and Tissue Stem Cell Committee of the International Society for Cellular Therapy called them "mesenchymal stem cells" (MSCs) and gave the minimum criteria that define a set of markers and characteristics of MSCs. These criteria are generally accepted today and include the ability to self-renew, multipotency with osteogenic, chondrogenic, and adipogenic potentials, and expression of surface markers such as the cluster of differentiation CD73, CD90, and CD105 while lacking CD14, CD34, CD45, and human leukocyte antigen-DR (HLA-DR). The characteristics of human MSCs vary depending on the tissues from which they are obtained, the method of isolation, and cultivation. An important parameter in the cultivation of MSCs is the used medium [11-13].

The original source of MSC was bone marrow. Studies to date have shown that various sources, such as bone, cartilage, tendons, muscles, adipose tissue, and hematopoietic stromal tissue, can be used to obtain a differentiated population of MSCs. Due to the small number of MSCs and the fact that the procedure of obtaining MSCs from the bone marrow is painful and requires the use of anesthesia, over time, adipose tissue and umbilical cord tissue became the source of MSCs with the greatest potential [12].

Multipotency has made them attractive for regenerative medicine and the regeneration of damaged tissue. They stimulate tissue regeneration by increasing vascularization and reducing inflammation, but they also secrete neutrophil factors and inhibit apoptotic signaling. On the other hand, their secretory activity and the secretion of soluble factors, which could be responsible for the immunomodulatory properties of MSCs, make them even more attractive for medical use. Today, it is generally accepted that MSCs achieve a more significant effect by secreting paracrine factors than by replacing cells. Of particular importance are the extracellular vesicles, which contain regulatory miRNAs, cytokines, and growth factors, as well as 
signaling lipids. Undoubtedly, MSCs could be of great importance in the treatment of various diseases in the future $[12,14]$.

\section{MESENCHYMAL STEM CELLS IN THE TREATMENT OF COVID-19}

Treatment of patients with COVID-19 depends on the severity of the clinical picture. In general, therapy could be divided into antiviral therapy, immunotherapy, and adjunctive therapy [5].

Several studies have shown that the key moment in the pathogenesis of SARS-CoV-2- infection is the recognition of ACE2 receptor of the host cell by virus spike protein. In addition to ACE2, the role of the cellular transmembrane protease, serine 2 (TMPRSS2) is important for cell entry by the virus. Numerous human cells have ACE2 on their surface, especially alveolar type 2 (AT2) and capillary epithelium. AT2 cells also have TMPRSS2 on their surface. It is interesting that lymphohematopoietic tissues (lymph nodes, bone marrow, spleen), T and B lymphocytes, and macrophages are always negative for ACE2. The fact is that almost all endothelial cells and smooth muscle cells have ACE2, which also explains the spread of the virus throughout the body. On the other hand, the ability of the virus to spread throughout the body explains the fact that patients with a severe clinical presentation may have acute myocardial injury, arrhythmia, acute kidney injury, shock, and multiorgan dysfunction syndrome $[15,16]$.

Most patients who have COVID-19 are asymptomatic or have a mild clinical presentation. However, in some patients, disease progression occurs with the onset of respiratory failure, acute respiratory distress syndrome (ARDS), septic shock, multiple organ dysfunction syndrome (MODS), and death. The main cause of death is respiratory failure, but dysfunction of the liver, kidneys, heart, and other vital organs is possible. It is likely that the leading cause of tissue and organ damage is a virus-induced cytokine storm. It occurs due to excessive activity of the host immune system during infection, first locally, as a severe inflammatory response, and then spreads systemically, resulting in tissue damage. It is believed that the result of the imbalance is in the regulation of the immune system. Numerous proinflammatory cytokines (IL-6, TNF, IL-1, IL-2, IL-17, IFN- $\gamma$, G-CSF, macrophage inflammatory protein 1, IFN$\gamma$-induced protein 10 , and others) were significantly elevated in patients with a severe clinical presentation. Therefore, the assumption is that avoiding a cytokine storm would be crucial in the treatment of COVID-19, especially in patients with a severe clinical presentation. MSCs, due to their immunomodulatory ability, could be significant in the prevention and attenuation of the cytokine storm. Additionally, previous clinical tri- als have shown that there were no adverse reactions and that MSCs use was safe and effective [15-17].

After intravenous administration, part of the MSCs reaches the lungs where they could recover the pulmonary microenvironment, protect alveolar epithelial cells, intercept pulmonary fibrosis, and cure lung dysfunction and COVID-19 pneumonia. A limitation in their application may be the speed at which it is possible to isolate MSCs from tissue, such as bone marrow, cord blood, adipose tissue, and others, and propagate them in cell culture. The results of clinical studies on the use of MSCs in patients with autoimmune diseases, such as type 2 diabetes mellitus, graft versus host disease after allogeneic hematopoietic stem cells transplantation, spinal cord injury, and others, as well as in patients with H5N1 infection initiated studies on the use of MSCs in patients with respiratory failure due to COVID-19 [16].

By searching the PubMed search engine for keywords "mesenchymal stem cells" and "COVID-19", we found 77 papers that have been published in the last few months, i.e., since the outbreak of the pandemic, and they relate to the use of mesenchymal stem cells in patients with COVID-19. Furthermore, 37 clinical studies about the use of MSCs in patients with COVID-19 were registered on the ClinicalTrials.gov website. These studies include 18/37 recruiting, 10/37 not yet recruiting, 4/37 active not recruiting, 3/37 enrolling by invitation, 1 withdrawn, and 1 completed. Clinical studies regarding the use of MSCs in the treatment of severe COVID-19 are conducted in 15 countries. The largest number of clinical studies has been reported in China (9/37) and the United States of America (8/37), but also in other countries, such as Spain, Pakistan, Mexico, Jordan, Brazil, Iran, United Kingdom, Belarus, Ukraine, Colombia, Indonesia, Germany, and Turkey. The only completed study is "Treatment With Human Umbilical cord-derived Mesenchymal Stem Cells for Severe Corona Virus Disease 2019 (COVID-19)". The study is multicenter, randomized, double-blind, placebo-controlled, and in phase II. It started on March 5th, 2020, and finished on May 12th, 2020, enrolling 100 participants. It took place in China, Wuhan, Huoshenshan Hospital, Maternal and Child Health Hospital of Hubei Province, General Hospital of Central Theater Command. The experimental group received 3 doses of MSCs from umbilical cord blood on days 0,3 , and 6 . The goal of the clinical trial was to inspect the safety and efficacy of mesenchymal stem cells (MSCs) therapy for severe COVID-19. The results of the study have not yet been published. As of May 6th, 2020, a total of 40 clinical studies have been registered in ChiCTR and $\mathrm{NIH}$, dealing with the efficient and safe use of MSCs in patients with severe COVID-19 [18-21].

In April 2020, Leng and co-workers published the results of a pilot study on the use of MSCs in 7 patients with a severe clinical picture in whom there was no favorable therapeutic response to standard therapy. The 
study, which was conducted from January 23rd, 2020 to February 16th, 2020, included patients aged 18-95 years. In all patients, 2-4 days after MSC administration, there was an improvement, i.e., the disappearance of symptoms associated with a severe clinical picture of COVID-19 and improved oxygen saturation. Studies have confirmed that MSCS are ACE2- and TMPRSS2negative and play the vital immune modulation roles to reverse the lymphocytes subsets mainly through dendritic cells. After the application of MSCs, there was a significant decrease in the values of proinflammatory cytokines and chemokines, reduction in the number of mononuclear cells and macrophages at the site of inflammation in the lungs, and increased recruitment of dendritic cells at the site of inflammation [22].

The cytokine storm, which is crucial for the progression of COVID-19, is amplified by the parallel processes that occur. Macrophages and other antigen-presenting cells are activated, which warn lymphocytes of the presence of the virus, while virus replication in host cells and increased synthesis of proinflammatory cytokines, as well as increased apoptosis due to viral invasion. Based on this knowledge, and in an effort to prevent and reduce the severity of the cytokine storm, Sengupta et al. applied exosomes derived from allogeneic bone marrow mesenchymal stem cells, a complex mix of signaling nanovesicles secreted by bmMSCs, a novel, multitargeted, next-generation biologic agent in a prospective nonrandomized open-label cohort study. Recovery occurred in 17/24 (71\%) patients with a severe clinical picture of COVID-19. After one treatment, patients' clinical status and oxygenation improved. There was a significant reduction in the levels of the acute phase reactants (CRP, ferritin, and D-dimer) and a significant decrease in the number of neutrophils, and an increase in the number of lymphocytes. Although this first clinical study showed that there was a significant improvement after exosomes administration in patients with severe COVID-19 further studies are needed to determine the efficacy and safety of this therapy [23].

So far, a clinical study (pilot study as well as a single case study) on the use of MSCs in patients with severe COVID-19 has shown that the general condition improves in a large percentage of treated patients and that after intravenous administration of MSCs in patients' blood increases cell populations such as CD14 ${ }^{+}$CD11 $c^{+}$CD11bMid regDCs, lower TNF-a levels significantly, and increase serum IL-10 levels. The level of serum bilirubin, C-reactive protein, aspartate aminotransferase, and alanine aminotransferase decreases dramatically, the number of leukocytes and neutrophils decreases, and the number of lymphocytes normalizes. Preliminary results of previous studies on the use of MSCs in the treatment of patients with severe COVID-19, who had pneumonia and ARDS, show that there is an improvement in lung function, but also a lower incidence of multiorgan dysfunction, better sur- vival, and reduced mortality. The results of previous studies indicate that MSCs cell therapy is safe and effective in patients with a severe clinical presentation of SARS-COV-2 virus infection $[24,25]$.

\section{CONCLUSION AND PERSPECTIVE}

There is probably no topic in human medicine that is more intriguing than the use of cell therapy and especially the use of stem cells. Without a doubt, stem cells could have great potential in the treatment of some congenital and acquired diseases, like diabetes, cardiovascular diseases, neurodegenerative diseases, degenerative muscular disorders, cancers, liver injuries, hematopoietic and immune system disorders, metabolic disorders, graft-versus-host disease, sepsis, and ARDS. In recent years, special attention has been drawn to MSCs due to their anti-inflammatory, immunomodulatory and homing properties as well as regenerative potential. Numerous clinical studies are underway on the possible use of MSCs in patients with severe COVID-19 in whom lung and other vital organ damage have occurred. However, in order to draw definite conclusions regarding their safe and effective application, it is necessary to conduct controlled clinical studies, which sometimes takes years or even decades. In recent years, we have, unfortunately, witnessed numerous abuses in cell therapy $[24,26]$.

\section{REFERENCES}

1. Vabret N, Britton GJ, Gruber C, Hegde S, Kim J, Kuksin $M$, et al. Sinai Immunology Review Project. Immunology of COVID-19: Current State of the Science. Immunity 2020;16:52:910-41.

2. Abd El-Aziz TM, Stockand JD. Recent progress and challenges in drug development against COVID-19 coronavirus (SARS-CoV-2) - an update on the status. Infect Genet Evol 2020;83:104327.

3. https://www.who.int/docs/default-source/coronaviruse/situation-reports/20200807-covid-19-sitrep-200. pdf?sfvrsn=2799bc0f_2

4. Rogers CJ, Harman RJ, Bunnell BA, Schreiber MA, Xiang C, Wang FS, Santidrian AF, Minev BR. Rationale for the clinical use of adipose-derived mesenchymal stem cells for COVID-19 patients. J Transl Med 2020;18:203.

5. COVID-19 Treatment Guidelines Panel. Coronavirus Disease 2019 (COVID-19) Treatment Guidelines. National Institutes of Health. Available at ttps://www.covid19treatmentguidelines.nih.gov/. Accessed August $8^{\text {th }}, 2020$.

6. Yang L, Liu S, Liu J, Zhang Z, Wan X, Huang B, Chen Y, Zhang Y. COVID-19: immunopathogenesis and immunotherapeutics. Signal Transduct Target Ther 2020;5:128.

7. Azkur AK, Akdis M, Azkur D, Sokolowska M, van de Veen W, Brüggen MC, O'Mahony L, Gao Y, Nadeau K, Akdis CA. Immune response to SARS-CoV-2 and mechanisms of immunopathological changes in COVID-19. Allergy 2020;75:1564-81. 
8. Galipeau J, Sensébé L. Mesenchymal Stromal Cells: Clinical Challenges and Therapeutic Opportunities. Cell Stem Cell 2018;22:824-33.

9. Kim N, Cho SG. Clinical applications of mesenchymal stem cells. Korean J Intern Med 2013;28:387-402.

10. Friedenstein AJ, Deriglasova UF, Kulagina NN, Panasuk AF, Rudakowa SF, Luriá EA, Rudakow IA. Precursors for fibroblasts in different populations of hematopoietic cells as detected by the in vitro colony assay method. Exp Hematol 1974;2:83-92.

11. Uder C, Brückner S, Winkler S, Tautenhahn HM, Christ B. Mammalian MSC from selected species: Features and applications. Cytometry A 2018;93:32-49.

12. Mushahary D, Spittler A, Kasper C, Weber V, Charwat V. Isolation, cultivation, and characterization of human mesenchymal stem cells. Cytometry A 2018;93:19-31.

13. Kim N, Cho SG. Clinical applications of mesenchymal stem cells. Korean J Intern Med 2013;28:387-402.

14. Nolta JA, Galipeau J, Phinney DG. Improving mesenchymal stem/stromal cell potency and survival. Proceedings from the International Society of Cell Therapy (ISCT)MSC preconference held in May 2018, Palaisdes Congres de Montreal, Organized by the ISCT MSC Scientific Committee. Cytotherapy 2020; 22:123-6.

15. Atluri S, Manchikanti L, Hirsch JA. Expanded Umbilical Cord Mesenchymal Stem Cells (UC-MSCs) as a Therapeutic Strategy in Managing Critically III COVID-19 Patients: The Case for Compassionate Use. Pain Physician 2020;23:E71-E83.

16. Golchin A, Seyedjafari E, Ardeshirylajimi A. Mesenchymal Stem Cell Therapy for COVID-19: Present or Future. Stem Cell Rev Rep 2020;16:427-433.

17. Wang J, Jiang M, Chen X, Montaner LJ. Cytokine storm and leukocyte changes in mild versus severe SARSCoV-2 infection: Review of 3939 COVID-19 patients in China and emerging pathogenesis and therapy concepts. J Leukoc Biol 2020;108:17-41.
18. https://pubmed.ncbi.nlm.nih.gov/?term=mesenchyma I+stem+cells+and+covid-19\&filter=datesearch.y_1

19. https://clinicaltrials.gov/ct2/results?cond=mesenchym al+stem+cells+and+COVID-19\&term $=\&$ cntry $=\&$ state $=$ \&city $=\&$ dist $=$

20. https://clinicaltrials.gov/ct2/show/NCT04288102 ?cond=mesenchymal+stem +cells+and+COVID19\&draw $=4 \&$ rank $=11$

21. Wang J, Jiang M, Chen $X$, Montaner LJ. Cytokine storm and leukocyte changes in mild versus severe SARSCoV-2 infection: Review of 3939 COVID-19 patients in China and emerging pathogenesis and therapy concepts. J Leukoc Biol 2020;108:17-41.

22. Leng $Z$, Zhu R, Hou W, Feng $Y$, Yang $Y$, Han $Q$, et al. Transplantation of ACE2(-) Mesenchymal Stem Cells Improves the Outcome of Patients with COVID-19 Pneumonia. Aging Dis 2020;11:216-28.

23. Sengupta $V$, Sengupta $S$, Lazo A, Woods $P$, Nolan A, Bremer N. Exosomes Derived from Bone Marrow Mesenchymal Stem Cells as Treatment for Severe COVID-19. Stem Cells Dev 2020;29:747-54.

24. Gupta A, Kashte S, Gupta M, Rodriguez HC, Gautam SS, Kadam S. Mesenchymal stem cells and exosome therapy for COVID-19: current status and future perspective. Hum Cell 2020:1-12.

25. Qu W, Wang Z, Hare JM, Bu G, Mallea JM, Pascual JM, et al. Cell-based therapy to reduce mortality from COVID-19: Systematic review and meta-analysis of human studies in acute respiratory distress syndrome. Stem Cells Transl Med 2020;9:1007-22.

26. Vujić $D$, Simić $M$, Zečević Ž. Istine i zablude o ćeliskoj terapiji u humanoj medicini. U: Đorđević $\mathrm{M}_{\text {, }}$ urednik. Problemi u pedijatriji 2016, Beograd: Zavod za udžbenike i nastavna sredstva, 2016; 37:175-81.

\section{Mezenhimalne matične ćelije i COVID-19}

\author{
Dragana Vujić ${ }^{1,2}$, Marija Simić ${ }^{2}$ \\ 1 Univerzitet u Beogradu, Medicinski \\ fakultet \\ 2 Institut za zdravstvenu zaštitu majke i \\ deteta Srbije „Dr Vukan Čupić", Radoja \\ Dakića 6-8, 11070 Beograd, Srbija
}

\begin{abstract}
Kratak sadržaj
Sa pojavom prvih slučajeva COVID-19 infekcije sa teškom kliničkom slikom praćenom respiratornom nedovoljnošću, kao i multiorganskom disfunkcijom, mezenhimalne matične ćelije postale su predmet intenzivnih istraživanja. Smatra se da je osnovni uzrok oštećenja tkiva i organa kod bolesnika sa COVID-19 infekcijom citokinska oluja, koja je rezultat poremećaja ravnoteže u regulaciji imunskog sistema domaćina. Dosadašnjim ispitivanjima utvrđeno je da mezenhimalne matične ćelije imaju imunomodulatorni efekat i da mogu da preveniraju i umanje citokinsku oluju pokrenutu SARS-Cov-2 virusom. U toku su brojne kliničke studije o primeni mezenhimalnih matičnih ćelija kod bolesnika sa teškom kliničkom slikom COVID-19. Nesumnjivo je da bi ćelijska terapija mogla imati veliki značaj u lečenju bolesnika sa teškom kliničkom slikom COVID-19, ali je potrebno vreme da se sagleda efikasnost i sigurnost ovakve terapije, što je moguće jedino kroz kontrolisane multicentrične kliničke studije.
\end{abstract}

Ključne reči: Mezenhimalne matične ćelije; Terapija; COVID-19. 